\section{Cureus}

Received 07/28/2015

Review began 09/16/2015

Review ended 09/22/2015

Published 09/28/2015

\section{(C) Copyright 2015}

Patel et al. This is an open access article distributed under the terms of the Creative Commons Attribution License CC-BY 3.0., which permits unrestricted use, distribution, and reproduction in any medium, provided the original author and source are credited.

\title{
Spontaneous Thrombosis and Subsequent Recanalization of a Developmental Venous Anomaly
}

Vishal J. Patel ${ }^{1}$, Rishi R. Lall ${ }^{1}$, Sohum Desai ${ }^{2}$, Aaron Mohanty ${ }^{1}$

1. Division of Neurosurgery, University of Texas Medical Branch at Galveston 2. Neuroscience, Doctors Hospital Renaissance, Edinburg, Texas, Usa

$\square$ Corresponding author: Sohum Desai, skdesai@utmb.edu

Disclosures can be found in Additional Information at the end of the article

\section{Abstract}

Developmental venous anomalies (DVA) are among the most common congenital malformations of the cerebral angioarchitecture. Spontaneous thrombosis of this entity is rare, and our review of the literature found only 31 reported cases of symptomatic spontaneous thrombosis of developmental venous anomalies. Here, we report a unique case describing the spontaneous thrombosis of a DVA leading to venous infarction and subsequent recanalization. The patient was a previously healthy 21-year-old male who presented with an acute onset of partial seizures. Following negative hypercoagulability studies and along with CT (computed tomography) and MR (magnetic resonance) imaging, the patient was treated with anticoagulant therapy and demonstrated complete functional recovery. Knowledge from our literature review of similar cases combined with the experience gained from this patient's treatment leads us to suggest that spontaneous DVA thrombosis and venous infarction generally has a good outcome despite initially devastating neurologic deficits. Additionally, the rarity of spontaneous DVA thromboses lends itself to the need to identify possible predisposing risk factors, chief amongst these being hypercoagulopathies.

Categories: Neurology, Radiology, Neurosurgery

Keywords: developmental venous anomaly, Venous thromboembolism

\section{Introduction}

Developmental venous anomalies (DVA), also known as venous angiomas, are malformations of the cerebral venous drainage system. They have a reported incidence of up to $2.5 \%$ in postmortem autopsy, and they account for nearly 55\% of all cerebral vascular malformations discovered by radiographic study [1-3]. DVAs are frequently associated other neurovascular malformations, such as cavernous angiomas [1].

Spontaneous thrombosis of this entity is rare but has been reported sporadically in the literature (Table 1). Several reported instances occurred in patients with conditions predisposing to hypercoagulabilities, such as Factor V Leiden mutation, smoking, and oral contraceptive use [4-5]. Although the majority of these lesions are benign, they can incur deficits related to increased arteriovenous shunting or venous congestion. In rare cases, DVAs may thrombose, leading to venous obstruction [6]. Here, we present a unique case of a symptomatic spontaneous DVA thrombosis with subsequent recanalization.

\section{Case Presentation}




\section{Cureus}

A previously healthy 21-year-old male presented with new onset partial seizures consisting of tonic-clonic activity affecting the left lower extremity in addition to numbness in the left upper extremity. His physical examination on presentation was significant for weakness in the left lower extremity, worse distally (1/5) than proximally (3/5). Initial coagulability studies, including PT, INR, and aPTT, were within normal limits (13.9 seconds, 1.0, and 28 seconds, respectively). A CT scan of the head without contrast, shown in Figure 1, revealed a $4.7 \mathrm{~cm} \mathrm{X}$ $2.4 \mathrm{~cm} \mathrm{X} 1.9 \mathrm{~cm}$ hypodensity along the medial aspect of the pre- and post-central gyri without significant mass effect. Informed patient consent was obtained for this patient's treatment.

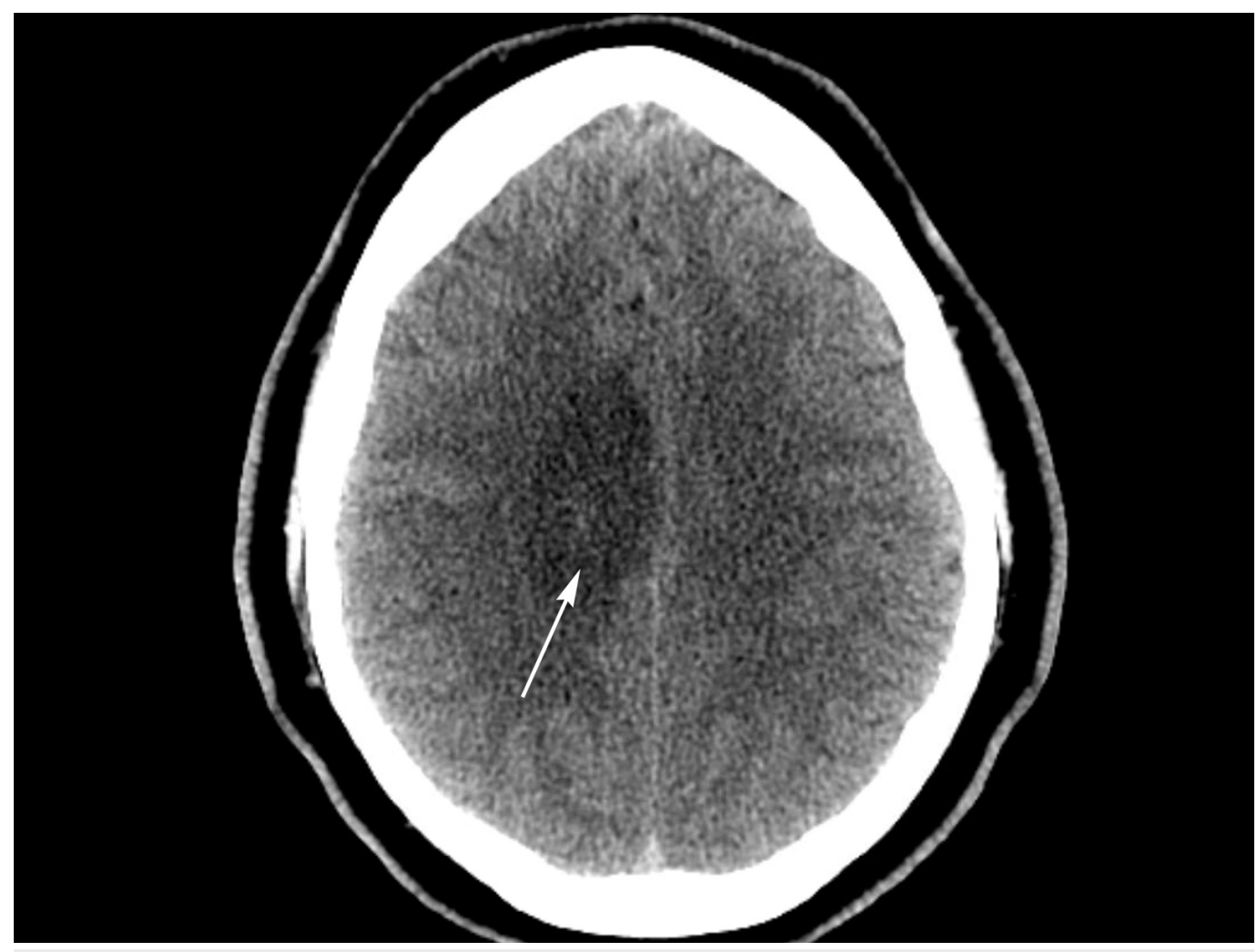

\section{FIGURE 1: Non-contrast CT head demonstrating vasogenic edema surrounding underlying DVA}

Given the suspicion for an underlying mass lesion, an MRI with contrast was obtained and demonstrated a prominent developmental venous anomaly draining into the superior sagittal sinus with significant peri-lesional vasogenic edema (Figure 2). No associated cavernous malformation was present. 


\section{Cureus}

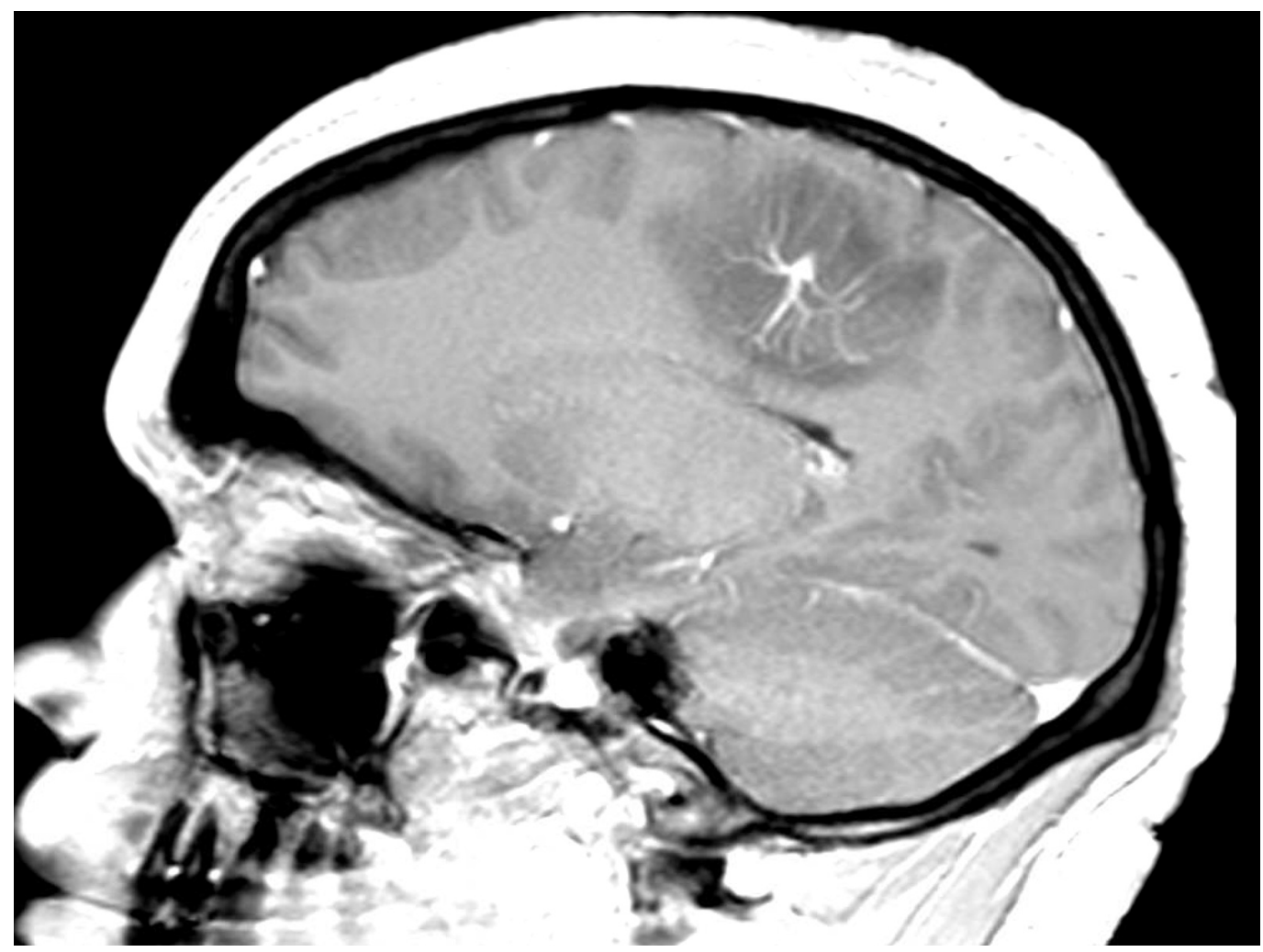

FIGURE 2: Contrasted MR demonstrating DVA and surrounding vasogenic edema

MR venography demonstrated non-filling of the venous angioma, suggesting that the draining vein had thrombosed (Figure 3).

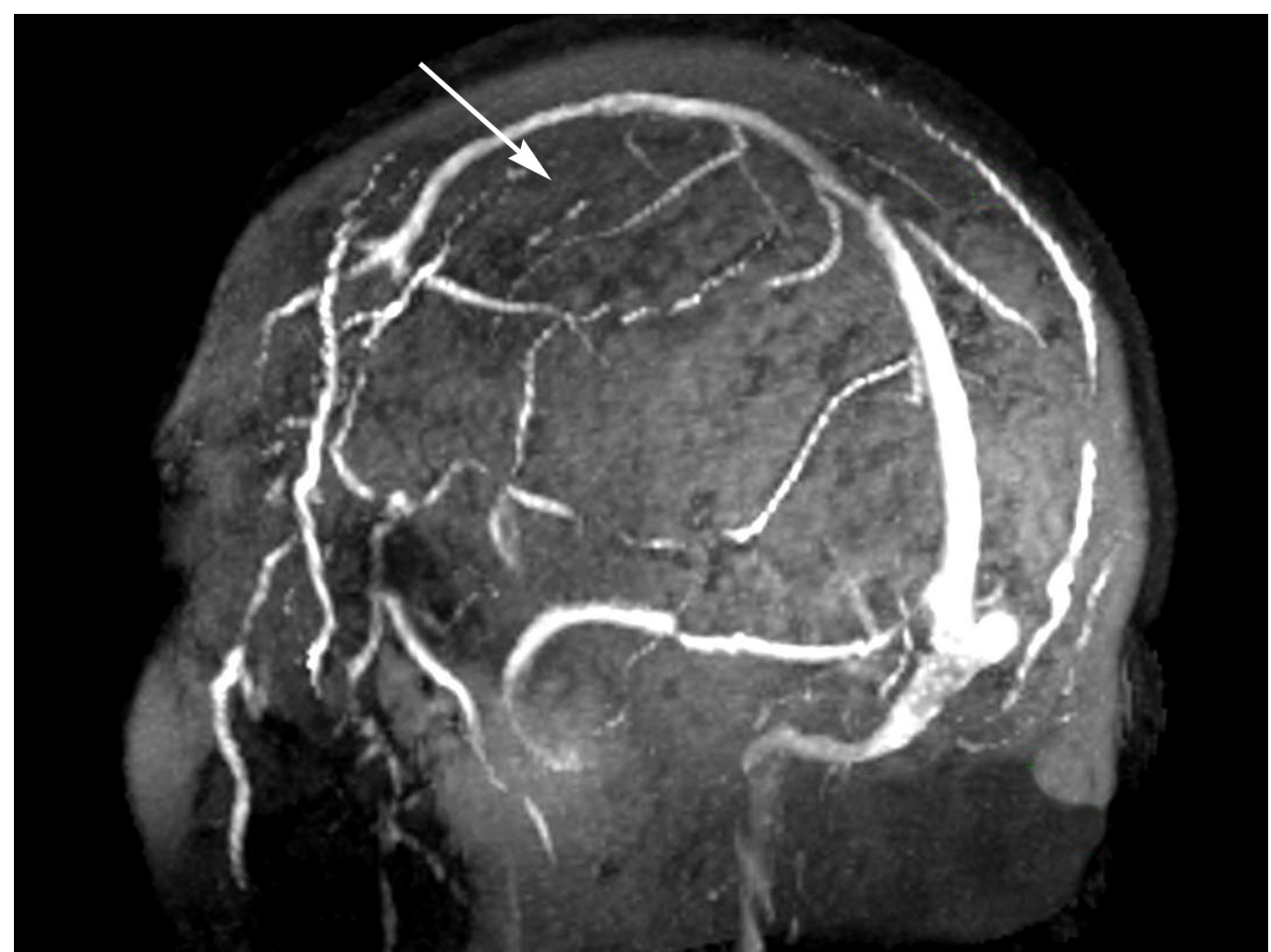




\section{Cureus}

\section{FIGURE 3: MR venogram demonstrating lack of flow through previously described DVA}

Following initial coagulability studies and after the collection of antithrombin III deficiency and Factor V Leiden mutation studies, the patient was started on intravenous heparin therapy. A four-vessel cerebral angiogram was then performed to evaluate for any other concurrent vascular lesions, such as a dural AV fistula (Figure 4). The arteriogram revealed the draining vein had recanalized.

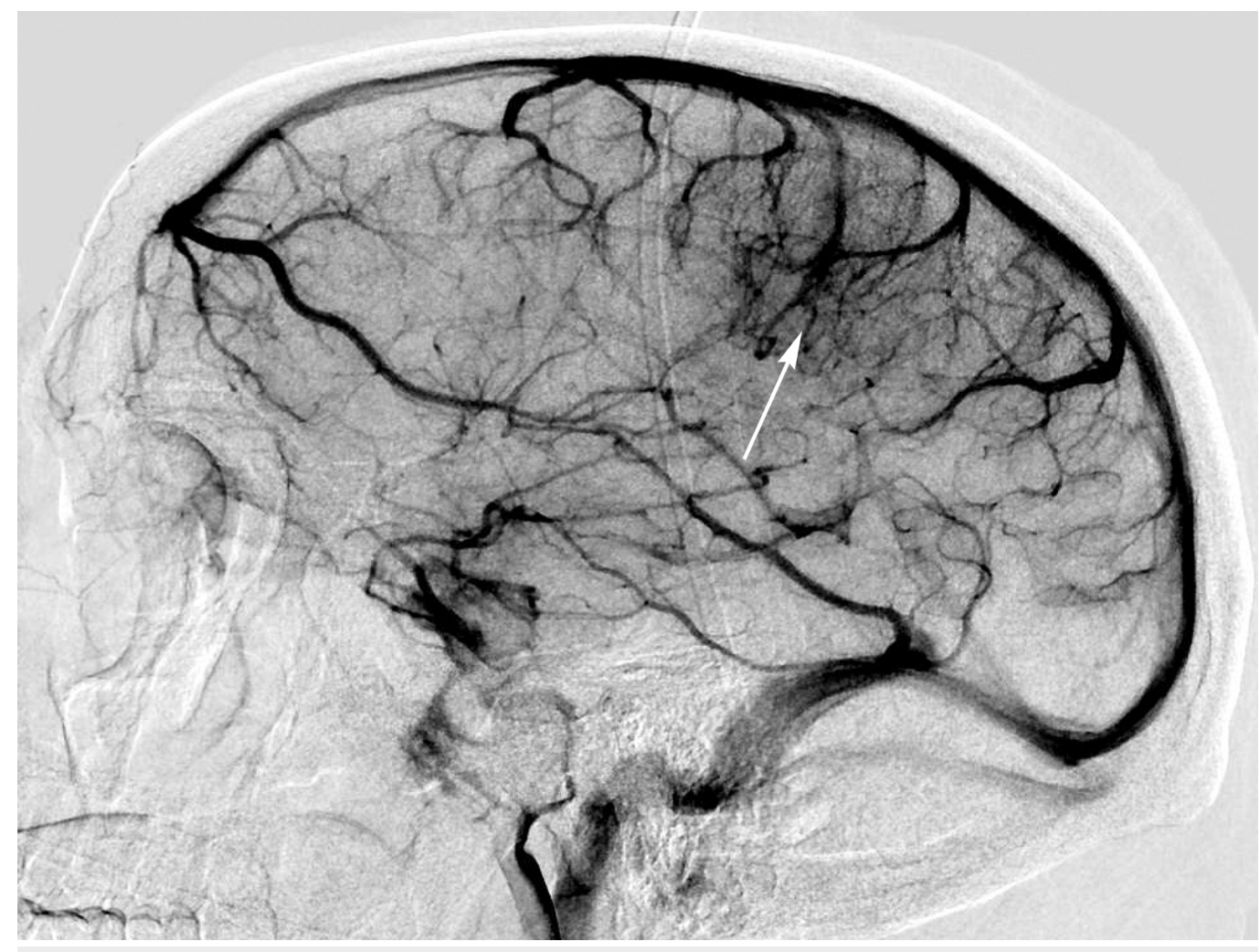

\section{FIGURE 4: Venous phase right internal carotid DSA demonstrating recanalization of previously mentioned DVA after IV heparin therapy}

By hospital day five, the patient had improved to $4 / 5$ in the proximal left lower extremity but remained 1/5 distally. The patient was then discharged on $81 \mathrm{mg}$ aspirin therapy.

Subsequent examination five weeks after presentation demonstrated the patient had complete recovery of sensation in his left upper extremity as well as strength in his left lower extremity. Activated protein C resistance assay for Factor V Leiden mutation (ratio of 2.3) and antithrombin III levels (97\%) were eventually found to be within normal limits. His aspirin therapy was discontinued in light of negative anticoagulation workup. A follow-up MRI scan three months post-discharge revealed laminar necrosis; however, his physical exam was negative for any sensory or strength deficits (Figure 5). 


\section{Cureus}

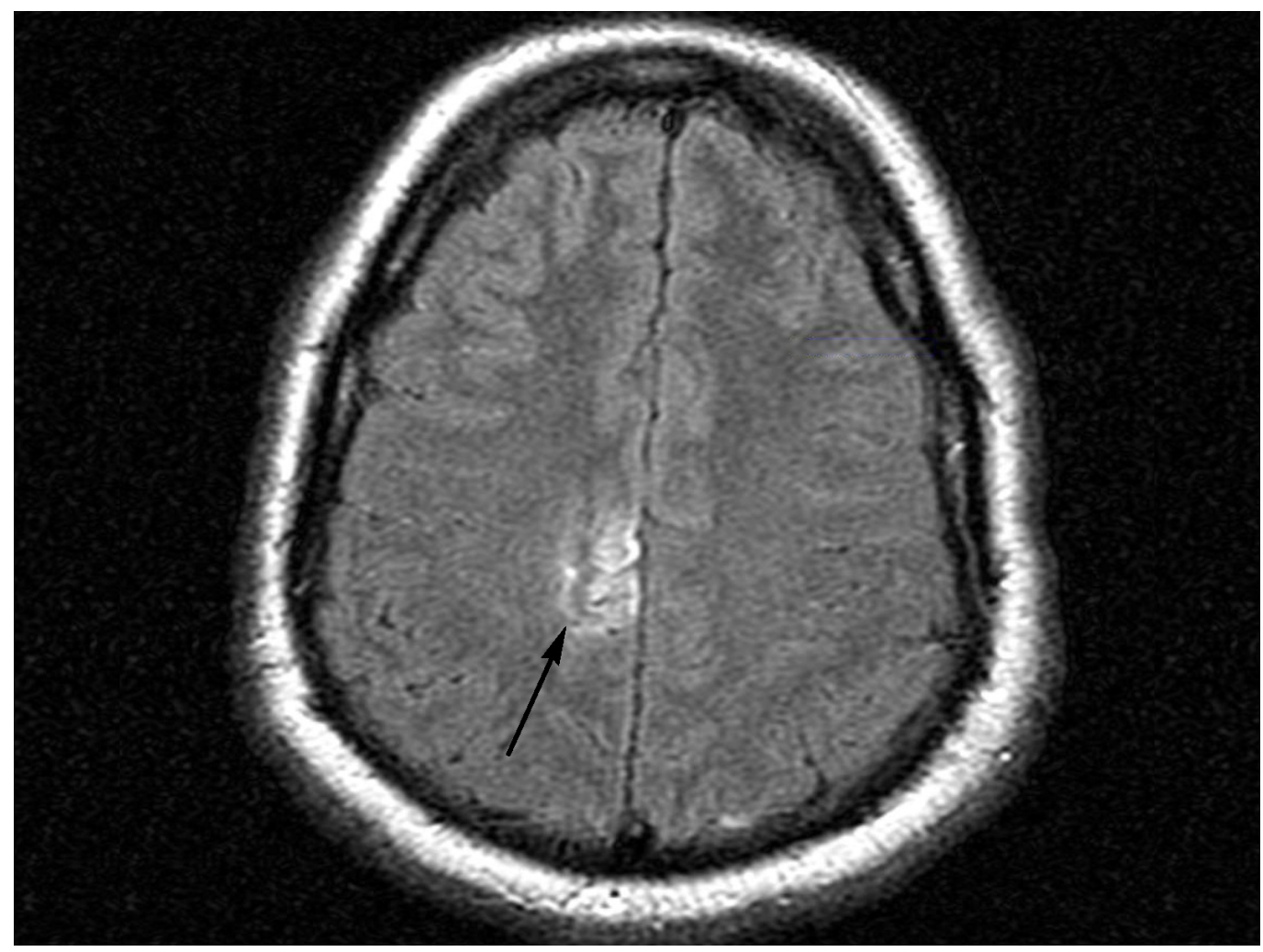

FIGURE 5: MR FLAIR demonstrating cortical laminar necrosis

The patient remains neurologically intact with no sensory deficits or weakness now one year from his initial presentation.

\section{Discussion}

Spontaneous thrombosis of a developmental venous anomaly is uncommon and has been limited to 31 cases described in the literature (Table 1).

\begin{tabular}{|c|c|c|c|c|c|}
\hline Author (Year) & Patient & DVA Location & Risk Factors & Management & Outcome \\
\hline $\begin{array}{l}\text { Agarwal, et al. } \\
(2014)[7]\end{array}$ & $\begin{array}{l}61 \text { yo } \\
\text { male }\end{array}$ & Left cerebellar & None reported & $\begin{array}{l}\text { Anticoagulation therapy } \\
\text { (type not specified) }\end{array}$ & $\begin{array}{l}\text { Improvement with } \\
\text { residual mild left- } \\
\text { sided ataxia }\end{array}$ \\
\hline $\begin{array}{l}\text { Yi, et al. } \\
(2013)[8]\end{array}$ & $\begin{array}{l}31 \text { yo } \\
\text { male }\end{array}$ & Left frontal & None reported & Conservative & $\begin{array}{l}\text { Improved neurological } \\
\text { function, but } \\
\text { developed } \\
\text { generalized seizures }\end{array}$ \\
\hline $\begin{array}{l}\text { Griffiths, et al. } \\
\text { (2013) [9] }\end{array}$ & $\begin{array}{l}52 \text { yo } \\
\text { male }\end{array}$ & Right pons & None reported & Warfarin & Complete recovery \\
\hline $\begin{array}{l}\text { Su, et al. } \\
(2013)[10]\end{array}$ & $\begin{array}{l}37 \text { yo } \\
\text { female }\end{array}$ & Left frontal & None reported & No treatment initiated & Complete recovery \\
\hline Pilato, et al. & 62 yo & Right & & Low-molecular-weight & \\
\hline
\end{tabular}




\section{Cureus}

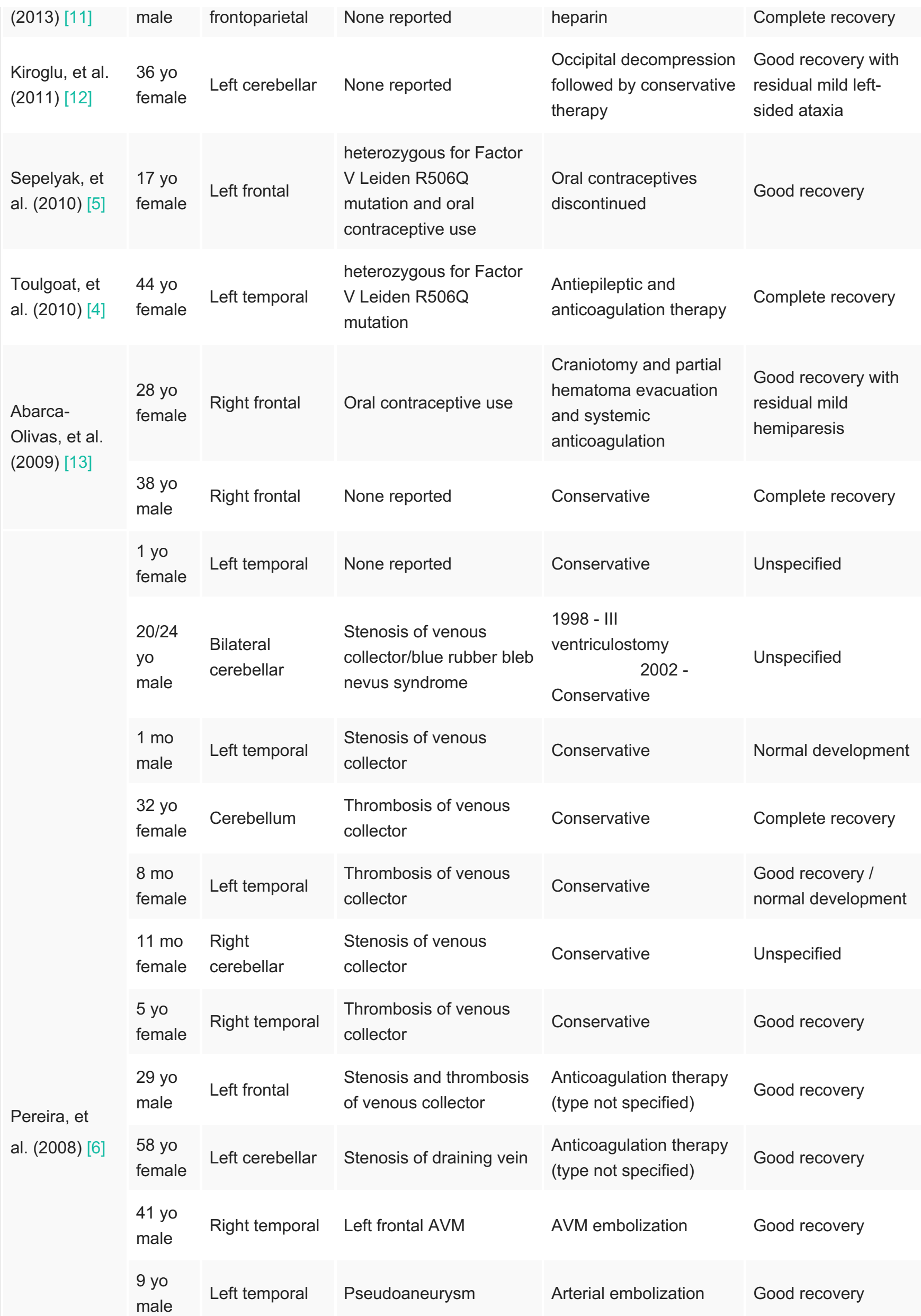




\section{Cureus}

\begin{tabular}{|c|c|c|c|c|c|}
\hline & $\begin{array}{l}14 \text { yo } \\
\text { female }\end{array}$ & $\begin{array}{l}\text { Bilateral } \\
\text { cerebellar }\end{array}$ & Microshunts & Arterial embolization & Good recovery \\
\hline & $\begin{array}{l}24 \text { yo } \\
\text { male }\end{array}$ & Right frontal & Microshunts & Arterial embolization & Good recovery \\
\hline & $\begin{array}{l}8 \text { yo } \\
\text { male }\end{array}$ & $\begin{array}{l}\text { Right } \\
\text { cerebellar }\end{array}$ & Microshunts & Arterial embolization & Good recovery \\
\hline & $\begin{array}{l}2 \text { day } \\
\text { female }\end{array}$ & Left frontal & Normal & Conservative & $\begin{array}{l}\text { Good recovery / } \\
\text { normal development }\end{array}$ \\
\hline & $\begin{array}{l}32 \text { yo } \\
\text { female }\end{array}$ & $\begin{array}{l}\text { Left basal } \\
\text { ganglia }\end{array}$ & Normal & Conservative & Good recovery \\
\hline & $\begin{array}{l}42 \text { yo } \\
\text { female }\end{array}$ & Left cerebellar & Normal & Conservative & Unspecified \\
\hline $\begin{array}{l}\text { Konan, et al. } \\
\text { (1999) [14] }\end{array}$ & $\begin{array}{l}31 \text { yo } \\
\text { male }\end{array}$ & $\begin{array}{l}\text { Bilateral } \\
\text { cerebellar }\end{array}$ & None reported & Conservative & $\begin{array}{l}\text { Residual right facial } \\
\text { palsy }\end{array}$ \\
\hline $\begin{array}{l}\text { Merten, et al. } \\
(1998)[15]\end{array}$ & $\begin{array}{l}50 \text { yo } \\
\text { female }\end{array}$ & Left frontal & None reported & Intravenous heparin & Complete recovery \\
\hline $\begin{array}{l}\text { Field and } \\
\text { Russell (1995) } \\
\text { [16] }\end{array}$ & $\begin{array}{l}34 \text { yo } \\
\text { female }\end{array}$ & $\begin{array}{l}\text { Right } \\
\text { parietotemporal }\end{array}$ & None reported & Conservative & Unspecified \\
\hline
\end{tabular}

TABLE 1: Reported Cases of Symptomatic Thrombosis of Developmental Venous Anomalies

The average age of patients was 27.9 years (range: 2 days to 62 years), and there appeared to be no gender predilection. Prognosis generally appears to be good with $73 \%$ of reported cases having a good or complete recovery and 83\% having improvement of any kind. In our review of the literature, therapy ranged widely from serial observation to anticoagulation.

Notably, though the patient eventually achieved full functional recovery, we observed that clinical improvement lagged behind radiographic resolution. Experience gained from this patient's treatment and from previously reported cases of DVA thrombosis suggests that physicians and family should not despair if clinical improvement is delayed or if presentation is late.

Although developmental venous anomalies are rarely symptomatic, they are common anatomical variants. Most patients with DVAs are told this finding is purely incidental and warrants no major concern. However, we propose a few caveats to this practice. First, spontaneous DVA thrombosis and venous infarction, although rare, should be included on the differential diagnosis for patients with a DVA presenting with new neurologic deficits. Correctly differentiating lesions caused by thrombosed DVAs from other pathologies, such as neoplasms, allows for the quicker initiation of the appropriate therapy. Second, patients with incidentally discovered DVAs should be offered screening for coagulopathies to help assess the risk of thrombosis, especially if the DVA is draining in eloquent territories. Although coagulability 
workup was unrevealing in this particular patient, the literature contains several instances of a DVA thrombosing in patients with predisposing hypercoagulable states [4-5]. Thrombosis in a young patient with no recent history of trauma, major surgery, or extended immobilization underlies the importance of a hypercoagulability workup to discover any additional risk factors.

\section{Conclusions}

Patients harboring developmental venous anomalies (DVA) should be aware that, although rarely symptomatic, these lesions can thrombose spontaneously and present with neurologic deficit.

\section{Additional Information Disclosures}

Human subjects: Consent was obtained by all participants in this study. University of Texas Medical Branch does not require approval for case reports. Informed patient consent was obtained. Conflicts of interest: In compliance with the ICMJE uniform disclosure form, all authors declare the following: Payment/services info: All authors have declared that no financial support was received from any organization for the submitted work. Financial relationships: All authors have declared that they have no financial relationships at present or within the previous three years with any organizations that might have an interest in the submitted work. Other relationships: All authors have declared that there are no other relationships or activities that could appear to have influenced the submitted work.

\section{References}

1. Töpper R, Jürgens E, Reul J, Thron A: Clinical significance of intracranial developmental venous anomalies. J Neurol Neurosurg Psychiatry. 1999, 67:234-38. 10.1136/jnnp.67.2.234

2. Sarwar M, McCormick W: Intracerebral venous angioma. Case report and review . Arch Neurol. 1978, 35:323-25. 10.1001/archneur.1978.00500290069012

3. Lee C, Pennington M, Kenney C: MR evaluation of developmental venous anomalies: medullary venous anatomy of venous angiomas. AJNR Am J Neuroradiol. 1996, 17:61-70.

4. Toulgoat F, Adams D, Nasser G, Ducreux D, Denier C: Intracerebral hemorrhage caused by thrombosis of developmental venous anomaly: total recovery following anticoagulation. Eur Neurol. 2010, 63:254-55. 10.1159/000277514

5. Sepelyak K, Gailloud P, Jordan L: Thrombosis of a developmental venous anomaly with hemorrhagic venous infarction. Arch Neurol. 2010, 67:1028. 10.1001/archneurol.2010.176

6. Pereira VM, Geibprasert S, Krings T, Aurboonyawat T, Ozanne A, Toulgoat F, Pongpech S, Lasjaunias PL: Pathomechanisms of symptomatic developmental venous anomalies . Stroke. 2008, 39:3201-15. 10.1161/STROKEAHA.108.521799

7. Agarwal A, Kanekar S, Kalapos P, Vijay K: Spontaneous thrombosis of developmental venous anomaly (DVA) with venous infarct and acute cerebellar ataxia. Emerg Radiol. 2014, 21:42730. 10.1007/s10140-014-1216-2

8. Yi KS, Cha SH, Min KS: Multimodal imaging follow-up of a thrombosed developmental venous anomaly: CT, CT angiography and digital subtraction angiography. Neurointervention. 2013, 8:120-24. 10.5469/neuroint.2013.8.2.120

9. Griffiths D, Newey A, Faulder K, Steinfort B, Krause M: Thrombosis of a developmental venous anomaly causing venous infarction and pontine hemorrhage. J Stroke Cerebrovasc Dis. 2013, 22:e653-55. 10.1016/j.jstrokecerebrovasdis.2013.04.033

10. Su IC, Krishnan P, Rawal S, Krings T: Magnetic resonance evolution of de novo formation of a cavernoma in a thrombosed developmental venous anomaly: a case report. Neurosurgery. 2013, 73:E739-44. 10.1227/NEU.0000000000000002

11. Pilato F, Calandrelli R, Gaudino S, Profice P, Martucci M, Esposito G, Colosimo C, Di Lazzaro V: Thrombosis of a developmental venous anomaly in inflammatory bowel disease: case report and radiologic follow-up. J Stroke Cerebrovasc Dis. 2013, 22:250-53.

10.1016/j.jstrokecerebrovasdis.2012.11.022 


\section{Cureus}

12. Kiroglu Y, Oran I, Dalbasti T, Karabulut N, Calli C: Thrombosis of a drainage vein in developmental venous anomaly (DVA) leading venous infarction: a case report and review of the literature. J Neuroimaging. 2011, 21:197-201. 10.1111/j.1552-6569.2009.00399.x

13. Abarca-Olivas J, Botella-Asunción C, Concepción-Aramendía LA, Cortés-Vela JJ, Gallego-León JI, Ballenilla-Marco F: Two cases of brain haemorrhage secondary to developmental venous anomaly thrombosis. Bibliographic review (Article in Spanish). Neurocirugia (Astur). 2009, 20:265-71. 10.4321/S1130-14732009000300005

14. Konan AV, Raymond J, Bourgouin P, Lesage J, Milot G, Roy D: Cerebellar infarct caused by spontaneous thrombosis of a developmental venous anomaly of the posterior fossa. AJNR Am J Neuroradiol. 1999, 20:256-58.

15. Merten CL, Knitelius HO, Hedde JP, Assheuer J, Bewermeyer H: Intracerebral haemorrhage from a venous angioma following thrombosis of a draining vein. Neuroradiology. 1998, 40:1518. $10.1007 / \mathrm{s} 002340050530$

16. Field LR, Russell EJ: Spontaneous hemorrhage from a cerebral venous malformation related to thrombosis of the central draining vein: demonstration with angiography and serial MR. AJNR Am J Neuroradiol. 1995, 16:1885-88. 